\title{
Article
}

\section{Quantification of chemotaxis-related alkane accumulation in Acinetobacter baylyi using Raman microspectroscopy}

\author{
Li, Hangbing, Martin, Francis L and Zhang, Dayi
}

Available at https://clok.uclan.ac.uk/17225/

Li, Hangbing, Martin, Francis L orcid iconORCID: 0000-0001-8562-4944 and Zhang, Dayi (2017) Quantification of chemotaxis-related alkane accumulation in Acinetobacter baylyi using Raman microspectroscopy. Analytical Chemistry (including News \& Features), 89 (7). pp. 3909-3918. ISSN 0003-2700

It is advisable to refer to the publisher's version if you intend to cite from the work. http://dx.doi.org/10.1021/acs.analchem.6b02297

For more information about UCLan's research in this area go to http://www.uclan.ac.uk/researchgroups/ and search for <name of research Group>.

For information about Research generally at UCLan please go to http://www.uclan.ac.uk/research/

All outputs in CLoK are protected by Intellectual Property Rights law, including Copyright law. Copyright, IPR and Moral Rights for the works on this site are retained by the individual authors and/or other copyright owners. Terms and conditions for use of this material are defined in the policies page. 
Subscriber access provided by Lancaster University Library

Article

\title{
Quantification of chemotaxis-related alkane accumulation in Acinetobacter baylyi using Raman microspectroscopy
}

\author{
Hanbing Li, Francis Luke L Martin, and Dayi Zhang
}

Anal. Chem., Just Accepted Manuscript • DOI: 10.1021/acs.analchem.6b02297 • Publication Date (Web): 03 Mar 2017

Downloaded from http://pubs.acs.org on March 3, 2017

\section{Just Accepted}

"Just Accepted" manuscripts have been peer-reviewed and accepted for publication. They are posted online prior to technical editing, formatting for publication and author proofing. The American Chemical Society provides "Just Accepted" as a free service to the research community to expedite the dissemination of scientific material as soon as possible after acceptance. "Just Accepted" manuscripts appear in full in PDF format accompanied by an HTML abstract. "Just Accepted" manuscripts have been fully peer reviewed, but should not be considered the official version of record. They are accessible to all readers and citable by the Digital Object Identifier (DOI®). "Just Accepted" is an optional service offered to authors. Therefore, the "Just Accepted" Web site may not include all articles that will be published in the journal. After a manuscript is technically edited and formatted, it will be removed from the "Just Accepted" Web site and published as an ASAP article. Note that technical editing may introduce minor changes to the manuscript text and/or graphics which could affect content, and all legal disclaimers and ethical guidelines that apply to the journal pertain. ACS cannot be held responsible for errors or consequences arising from the use of information contained in these "Just Accepted" manuscripts. 


\title{
Quantification of chemotaxis-related alkane accumulation in Acinetobacter baylyi using Raman microspectroscopy
}

\author{
Hanbing $\mathrm{Li}^{\mathrm{a}}$, Francis Luke L Martin ${ }^{\mathrm{a}, \mathrm{b}}$, Dayi Zhang ${ }^{\mathrm{a}, *}$ \\ ${ }^{a}$ Lancaster Environment Centre, Lancaster University, Lancaster, LA1 4YQ, UK \\ ${ }^{b}$ School of Pharmacy and Biomedical Sciences, University of Central Lancashire, \\ Preston PR1 2HE, UK
}

\begin{abstract}
*Corresponding author Dr Dayi Zhang, Lancaster Environment Centre, Lancaster University, Lancaster, LA1 4YQ, UK; Tel.: +44(0)1524510288; Fax: +44(0)1524510082; Email: d.zhang@lancaster.ac.uk
\end{abstract}




\begin{abstract}
Alkanes are one of the most widespread contaminants in the natural environment, primarily as a consequence of biological synthesis and oil spills. Many indigenous microbes metabolize alkanes, and the chemotaxis and accumulation in some strains has been identified. For the first time, we apply Raman microspectroscopy to identify such chemotaxis-related affinity, and quantify the alkane concentrations via spectral alterations. Raman spectral alterations were only found for the alkane chemoattractant bacteria Acinetobacter baylyi ADP1, not for Pseudomonas fluorescence, which exhibits limited chemotaxis towards alkane. The significant alterations were attributed to the strong chemotactic ability of A. baylyi enhancing the affinity and accumulation of alkane molecules on cell membranes or cellular internalization. Spectral fingerprints of $A$. baylyi significantly altered after 1-h exposure to pure alkanes (dodecane or tetradecane) and alkane mixtures (mineral oil or crude oil), but not monocyclic aromatic hydrocarbons (MAHs) or polycyclic aromatic hydrocarbons (PAHs). A semi-log linear regression relationship between Raman spectral alterations and alkane concentrations showed its feasibility in quantifying alkane concentration in environmental samples. Pure alkanes or alkane mixtures exhibited different limits of detection and regression slopes, indicating that the chemotaxis-related alkane accumulation in A. baylyi is dependent on the carbon chain length. This work provides a novel biospectroscopy approach to characterize the chemotaxis-related alkane bioaccumulation, and has immense potential for fast and high-throughput screening bacterial chemotaxis.
\end{abstract}

Keywords: Acinetobacter baylyi; Chemotaxis; Alkane; Affinity; Bioaccumulation; Raman microspectroscopy; Spectral fingerprints 


\section{Introduction}

Many hazardous chemicals have been released into the environment through various industrial activities. Particularly, with industrial development and urbanization processes, the increasing usage of crude oil has consequently been associated with numerous oil spill accidents and contaminated sites. Since 1969, there have been $>40$ large oil spill incidents worldwide, including the Exxon Valdez oil spill in Prince William Sound in $1989^{1,2}$, the Deepwater Horizon oil spill in Gulf of Mexico ${ }^{3}$ and the Xingang oil spill in Dalian ${ }^{4}$ in 2010. These incidents have resulted in large areas of oil-contaminated sites, damaged ecological systems and threats to human health ${ }^{5,6}$. Chemical analysis of alkanes predominantly includes gravimetric $^{7-9}$, fluorophotometry $^{10,11}$, infrared (IR) absorption ${ }^{12}$, gas chromatography flame ionization detector (GC-FID) ${ }^{13}$ or gas chromatography mass spectrometry (GC-MS) methods $^{14}$, but samples require pre-treatment using solvent extraction or solid-phase microextraction (SPME) ${ }^{15}$. To evaluate alkane bioavailability or bioaccessibility, some whole-cell bioreporters have been developed ${ }^{16}$ and even applied in real-world cases $^{4,17}$, but they suffer from relatively low reproducibility. Considering the rapid response required to oil spill incidents, it is necessary to develop some real-time and non-destructive screening tools to achieve fast and reliable detection of crude oil contamination.

In the natural environment, alkanes are the main components of crude oil and carbon sources for many bacteria, and alkane chemotaxis has been found in some species $^{18}$. Chemotaxis-related affinity to alkanes facilitates bacterial movement in alkane gradients and contributes to their elevated abilities to access and utilize alkane substrates $^{19}$. In Pseudomonas aeruginosa PAO1, the tlpS gene, which is located downstream of the alkane monooxygenase alkBl gene, is believed to encode a methyl-accepting chemotaxis protein (MCP) that confers the chemotactic response to hexadecane ${ }^{20}$. Another Pseudomonas strain, P. putida GPo1, has the alkN gene encoding an MCP for alkane chemotaxis ${ }^{21}$. Flavimonas oryzihabitans is reported to exhibit weak chemotactic responses to hexadecane but its mechanisms remain unknown $^{22}$. The alkane chemotaxis machinery of marine alkane degrader Alcanivorax dieselolei consists of eight cytoplasmic chemotaxis proteins, including MCP and flagellar proteins ${ }^{23}$. Acinetobacter baylyi is the bacterial species with the strongest alkane chemotaxis and accumulation ${ }^{16,24-26}$. In A. baylyi, the putative gene encoding 
an MCP is chpA which has high similarity to cheY (fused chemotactic sensory histidine kinase) and $o m p R$ (two-component response regulator) in Escherichia coli, suggesting potentially similar chemotaxis machinery. A. baylyi cells have high affinity only to alkane droplets, but not to other hydrophobic molecules ${ }^{16}$, suggesting that the MCP has high recognition specificity to linear alkanes. Meanwhile, alkane chemotaxis further helps microbial accumulation, internalization and degradation of alkanes by providing enhanced opportunities to seek out linear alkanes. The fimbriae on the surface of Acinetobacter cells are postulated to drive the access to alkane droplets for cellular uptake ${ }^{27-29}$. Trapped alkane droplets on the cell surface are subsequently transported into bacterial cells after being emulsified by biosurfactant mediation $^{30-32}$.

Raman microspectroscopy has been widely applied in biological molecule detection, as a fast, reproducible and non-destructive approach generating a chemical fingerprint ${ }^{33}$. It has been well developed to identify bacteria and study their responses to their environment ${ }^{34-37}$. Most spectrally-identified biological molecules are well characterized, such as purine, pyrimidine, amino acids and proteins ${ }^{38-42}$. Though many approaches, such as swarm plates ${ }^{43}$, capillary assays ${ }^{44}$, temporal stimulation of tethered cells ${ }^{45}$ and automated tracking of swimming cells ${ }^{46}$, have been applied to test the bacterial chemotaxis towards specific chemicals, there is still no study exploring Raman spectral alterations during chemotaxis-related affinity and bioaccumulation processes. The chemotactic behaviour of alkanes hints at the possibility that alkane molecules will accumulate on the membrane and/or in the cytoplasm of bacterial cells, potentially allowing them to be identified in Raman spectra.

In the present study, we used the Raman microspectroscopy to distinguish the spectral alterations and quantify alkane concentrations based on the chemotaxisrelated alkane accumulation of A. baylyi. For the first time, we demonstrate that chemotaxis-related alkane affinity and accumulation is measurable by Raman microspectroscopy and the MCP of A. baylyi is highly specific to alkane molecules, instead of monocyclic aromatic hydrocarbons (MAHs) or polycyclic aromatic hydrocarbons (PAHs). Not only contributing to fast quantification of aqueous alkane concentrations, this method also has the potential as a screening tool in characterising chemotaxis-related affinity and accumulation towards various chemicals. 


\section{Experimental section}

\section{Strains and Growth Conditions}

The two bacterial strains used in this study were the alkane chemotactic Acinetobacter baylyi ADP1 and chemotaxis-negative Pseudomonas fluorescence. Both strains were grown in minimal medium with $20 \mathrm{mM}$ sodium succinate as the sole carbon source, at $30^{\circ} \mathrm{C}$ and $150 \mathrm{rpm}$ for $16 \mathrm{~h}$. The 1.0 litre minimal medium contained $1.0 \mathrm{~g}\left(\mathrm{NH}_{4}\right)_{2} \mathrm{SO}_{4}$, $2.5 \mathrm{~g} \mathrm{KH}_{2} \mathrm{PO}_{4}, 0.1 \mathrm{~g} \mathrm{MgSO}_{4} \cdot 7 \mathrm{H}_{2} \mathrm{O}, 0.005 \mathrm{~g} \mathrm{FeSO}_{4} \cdot 7 \mathrm{H}_{2} \mathrm{O}, 0.25 \mathrm{~g}$ nitrilotriacetic acid (NTA), $0.55 \mathrm{~g} \mathrm{NaOH}$, and $1 \mathrm{~mL}$ Bauchop and Elsden solution. Strains were further centrifuged at 4,000 rpm for $5 \mathrm{~min}$ and washed three times using sterile deionized water, and finally suspended in minimal medium for further experimentation.

\section{Hydrocarbon exposure}

Unless specifically stated otherwise, all chemicals in this study were of analytical grade and purchased from Sigma Aldrich (UK). The hydrocarbons included six pure chemicals: dodecane, tetradecane, toluene, xylene, phenanthrene and naphthalene; and, two hydrocarbon mixtures: crude oil and mineral oil. They were dissolved in dimethyl sulfoxide (DMSO) to prepare the $10 \mathrm{~g} / \mathrm{L}$ stock solution, and serially diluted to $0.1-5.0$ $\mathrm{g} / \mathrm{L}$. The hydrocarbon stock solution was separately mixed with bacterial suspensions $(1: 100, \mathrm{v} / \mathrm{v})$ to reach a final concentration of $100 \mathrm{mg} / \mathrm{L}$. After 1 -h exposure at $30^{\circ} \mathrm{C}$, the medium was removed by $5 \mathrm{~min}$ centrifugation at 5,000 rpm, and the cell pellets were re-suspended in deionized water and washed twice.

The time-dependence of chemotaxis-related chemo-association was measured by exposing A. baylyi suspensions to dodecane, tetradecane, crude oil or mineral oil for $0.5,1,3$ and $5 \mathrm{~h}$ at $30^{\circ} \mathrm{C}$, respectively. The final alkane concentrations were $100 \mathrm{mg} / \mathrm{L}$. The cells were further centrifuged at 5,000 rpm for $7 \mathrm{~min}$, and washed twice by deionized water.

To establish the dose response of alkane accumulation, different volumes of dodecane, tetradecane, crude oil or mineral oil stock solution were added to $1 \mathrm{~mL}$ washed A. baylyi suspensions. The final concentrations were: 1, 2, 5, 10, 20, 50 and $100 \mathrm{mg} / \mathrm{L}$. After $1-\mathrm{h}$ exposure at $30^{\circ} \mathrm{C}$, the mixtures were centrifuged at 5,000 rpm for $7 \mathrm{~min}$, and washed twice by deionized water. 


\section{Hydrocarbon chemotaxis capillary test}

To validate chemotaxis effects, conventional capillary tests were applied according to Alder's protocol ${ }^{47}$ with some modifications. Briefly, the capillary tubes (internal diameter of $0.2 \mathrm{~mm}$ and length of $10 \mathrm{~cm}$ ) were plunged into $1 \mathrm{~mL}$ chemotaxis medium with attractant (alkanes, PAHs, MAHs and oils). After approximately $10 \mathrm{~min}$, the liquid was drawn up to approximately $1 \mathrm{~cm}$ the length of the tube, the capillary was then inserted (without rinsing) into the bacterial suspension (A. baylyi or $P$. fluorescence) and incubated for $1 \mathrm{~h}$ at $30^{\circ} \mathrm{C}$. To test the time-dependency of chemotaxis, the capillary tubes with tetradecane or crude oil attractants were incubated within the A. baylyi suspension for $0.5,1,3$ or $5 \mathrm{~h}$ at $30^{\circ} \mathrm{C}$, similar to the hydrocarbon exposure experiment described above.

Instead of plate counting, we used quantitative chain polymerase reaction (qPCR) to quantify the $16 \mathrm{~S}$ rRNA copy numbers of chemotactic bacterial in duplicate. After 1-h incubation, the capillary tube was removed and the exterior of the open end was directly plunged into qPCR buffer. The $10 \mu \mathrm{L}$ qPCR buffer consisted of $1 \mu \mathrm{L}$ of primer 314F (5'-CCTACGGGNGGCWGCAG-3'), $1 \mu \mathrm{L}$ of primer 802R (5'TACNVGGGTATCTAATCC-3'), $3 \mu \mathrm{L}$ molecular water and $5 \mu$ iTaq $^{\text {TM }}$ Universal SYBR® Green Supermix (BioRad, USA). The thermos cycling program was run complete except for the extra fluorescence data acquisition at $80^{\circ} \mathrm{C}$ for $15 \mathrm{~s}$ in each cycle. This was: initial denaturation at $94^{\circ} \mathrm{C}$ for $3 \mathrm{~min} ; 34$ amplification cycles of $94^{\circ} \mathrm{C}$ for $45 \mathrm{~s}, 52^{\circ} \mathrm{C}$ for $45 \mathrm{~s}, 72^{\circ} \mathrm{C}$ for $45 \mathrm{~s}$, and fluorescence data acquisition at $80^{\circ} \mathrm{C}$ for $15 \mathrm{~s}$. Standard curves were obtained with serial dilutions of quantified plasmid DNA (via nanodrop) containing the fragment of 16S rRNA, as described previously ${ }^{48}$.

\section{Chemical analysis of hydrocarbons}

After exposing chemotactic A. baylyi suspensions to hydrocarbon solutions, the determination of residual hydrocarbons at different time points was achieved by following the hexane extraction method ${ }^{48}$. At $0,0.5,1,3$ or $5 \mathrm{~h}$, the $50 \mathrm{~mL}$ cellhydrocarbon suspensions were added with $50 \mathrm{~mL}$ hexane and subsequently ultrasonically homologized for $2 \min (40 \mathrm{kHz})$. The supernatant was fractionalized by column chromatography, in which the hexane supernatant was loaded onto a glass column $\left(\Phi 10 \mathrm{~mm} \times 100 \mathrm{~mm}\right.$, consisting of $2 \mathrm{~cm}$ anhydrous $\mathrm{Al}_{2} \mathrm{O}_{3}$ and $0.3 \mathrm{~cm}$ anhydrous $\mathrm{Na}_{2} \mathrm{SO}_{4}$ from the bottom to the top) and washed with $50 \mathrm{~mL}$ hexane. The 
elution was evaporated in $40^{\circ} \mathrm{C}$ water bath and the hydrocarbons were measured by the gravimetric method.

\section{Raman Microspectroscopy Analysis}

Ten $\mu \mathrm{L}$ of washed cells were transferred onto a slide covered with aluminium foil and air-dried before Raman microspectroscopy analysis ${ }^{49}$. Raman spectra were obtained using an InVia confocal micro-Raman system (Renishaw, Gloucestershire, UK) equipped with a $100 \mathrm{~mW} 785 \mathrm{~nm}$ laser diode with a Rayleigh holographic edge filter. The spectrometer's entrance slit of $50 \mu \mathrm{m}$ combined with a 1200 lines per mm $\left(1 \mathrm{~cm}^{-1}\right.$ spatial resolution) diffraction grating allowed dispersion of Raman signals onto a Master Renishaw Pelletier cooled charged couple detector (CCD). A white light camera mounted on the microscope allowed the use of dark-field images to visualize locations for spectral acquisition. An attached microscope (Leica Microsystems, Milton Keynes, UK) with $\times 50$ objective $(0.75$ numerical aperture; $\approx 1 \mu \mathrm{m}$ spatial resolution) was utilized for sample detection and acquisition. All sample spectra were obtained using $100 \%$ laser power (26 $\mathrm{mW}$ at sample), $15 \mathrm{sec}$ acquisition time and one accumulation within a spectral range from 500 to $2000 \mathrm{~cm}^{-1}$. The Renishaw system was calibrated with a Renishaw silicon calibration source for wavenumber shifts. All the treatments were carried out in triplicates, and at least twenty biological replicates were performed and analysed for each sample.

\section{Raman Spectra Analysis}

Unless otherwise stated, all data were normalized and analysed using the IRootLab toolbox for Matlab (version R2013b, MathWorks, USA) ${ }^{50}$. Principal component analysis (PCA) was carried out to reduce the dimensionality of the multivariate data and allow visualization of the natural variance within the dataset ${ }^{51}$. Post-exposure to different alkane or oil concentrations, the distance of individual Raman spectra to that of comparator negative controls (alkane/oil concentration $=0 \mathrm{mg} / \mathrm{L}$ ) was calculated based on the values of principal component (PC) 1 (PC1) and PC2. The dispersions of individual group to negative control and pure alkane/oil groups were evaluated by output data derived from PCA and linear discriminant analysis (LDA) and were visualized as dispersion indicator $\left(D_{I}\right)$ scores plots, in which increasing $D_{I}$ between two categories is proportional to dissimilarity [details see Electronic Supplementary Information (ESI)]. The statistical significance of differences and variance analysis 
$(P$-value $<0.05)$ of LDA among the different treatments was performed using a oneway ANOVA and least significant difference (LSD) test.

\section{Results and Discussion}

\section{Raman spectral characterization of A. baylyi exposed to alkanes}

Exposed to alkanes or oil droplets, A. baylyi bacterial cells were predominantly found on the oil-water interface and could emulsify hydrocarbons into small droplets (see ESI Figure S1). The majority of $A$. baylyi cells were found on the alkane-water interface, not in the aqueous phase, demonstrating their high affinity to alkane droplets. In contrast, the strains negative for or with minor alkane chemotactic properties, like $P$. fluorescence, exhibited a very weak oil droplets affinity and most bacterial cells remained in the water phase (see ESI Figure S1). Similarly, the droplets of alkane mixtures (mineral oil) or hydrocarbon mixtures (crude oil) also showed strong attraction to A. baylyi, but no adhesion with P. fluorescence. A. baylyi ADP1 has been reported with high affinity to alkane droplets ${ }^{16}$, explained as alkane chemotaxis $^{43,52}$. From the results of hydrocarbon capillary assay (Figure. 2A), we confirmed the chemotaxis-related affinity of A. baylyi to alkanes. The accumulation of $16 \mathrm{~S}$ rRNA copies of $A$. baylyi in capillaries in oil mixture and pure alkane treatments ranged from $3.9 \times 10^{8}$ to $1.07 \times 10^{9}$ per capillary, significantly higher than those in PAHs and MAHs treatments $\left(8.7 \times 10^{5}\right.$ to $3.6 \times 10^{7} 16 \mathrm{~S}$ rRNA copies per capillary). In contrast, the low $16 \mathrm{~S}$ rRNA copy numbers of $P$. fluorescence in capillary tubes postexposure to oil mixtures and pure alkanes $\left(2.9 \times 10^{4}\right.$ to $9.7 \times 10^{6} 16 \mathrm{~S}$ rRNA copies per capillary) suggested that $P$. fluorescence is not an alkane chemotactic strain.

The hydrocarbon capillary assay proves that A. baylyi ADP1 cells can swim down the attractant gradient towards alkanes. From another perspective, MCP on the cell membranes of A. baylyi ADP1 effectively recognizes and binds the alkane molecules, eventually trapping and accumulating the soluble fraction of alkane molecules in the aqueous phase. Considering the low solubility of alkane in water, it generates the alkane gradient and contributes to the access of A. baylyi ADP1 cells to alkane molecules. This is strongly suggested by the significant accumulation of $A$. baylyi cells in capillary following exposure to alkane mixtures or pure alkanes (Figure 2A). Alkane chemotaxis significantly helps the internalization and utilization of the insoluble alkanes by A. baylyi ADP $1^{16}$. The accumulation of alkane molecules either 
on cell membranes or internalized within cells provides the opportunity to employ Raman microspectroscopy to investigate the chemotaxis-related affinity and accumulation of alkanes.

Since dodecane and tetradecane are both linear alkane molecules with carbon chain lengths of 12 and 14 respectively, their Raman spectra are similar (Figure 1A and Table 1, see ESI Figure S2A). The predominant bands include $890 \mathrm{~cm}^{-1}$ (terminal methyl $\mathrm{CH}_{3}$ rock), $1133 \mathrm{~cm}^{-1}$ (C-C asymmetric stretch and $\left.\mathrm{CH}_{2} \mathrm{wag}\right), 1297 \mathrm{~cm}^{-1}\left(\mathrm{CH}_{2}\right.$ twist) and $1439 \mathrm{~cm}^{-1}\left(\mathrm{CH}_{2} \text { bend }\right)^{53}$. The only difference between dodecane and tetradecane is the bands at $961 \mathrm{~cm}^{-1}$ and $1033 \mathrm{~cm}^{-1}$ in dodecane, which are attributed to $\mathrm{CH}_{2}$ rock ${ }^{54}$. As the distillation product of crude oil, the Raman spectra of mineral oil (see ESI Figure S2C) show distinct peaks at bands $1058 \mathrm{~cm}^{-1}$ and $890 \mathrm{~cm}^{-1}$, assigned to $\mathrm{CH}_{2}$ twist-rock and $\mathrm{C}-\mathrm{C}$ stretch, respectively ${ }^{55}$. Although the $\mathrm{CH}_{2}$ twist peak at $1297 \mathrm{~cm}^{-1}$ is observed for both crude oil and mineral oil, crude oil also contains MAHs and PAHs, and therefore possesses three unique peaks (Figure 1B): benzene ring breathing band $1060 \mathrm{~cm}^{-1}$, symmetric and antisymmetric $\mathrm{CH}_{2}$ scissors vibration bands $1437 \mathrm{~cm}^{-1}$ and $1459 \mathrm{~cm}^{-1} 56$. 
Table 1. Variations and assignments of Raman bands of alkanes and A. baylyi before and after exposure.

\begin{tabular}{|c|c|c|c|c|c|}
\hline $\begin{array}{l}\text { Band } \\
\left(\mathrm{cm}^{-1}\right)\end{array}$ & $\begin{array}{l}\text { Tentative bands } \\
\text { assignment }\end{array}$ & Origin & Alkane & A. baylyi & $\begin{array}{l}\text { Alkane + } \\
\text { A. baylyi }\end{array}$ \\
\hline 890 & $\begin{array}{l}\text { Terminal methyl } \\
\mathrm{CH}_{3} \text { rock }\end{array}$ & $\begin{array}{c}\text { Dodecane, tetradecane, } \\
\text { mineral oil }\end{array}$ & ++ & - & $+\uparrow$ \\
\hline 961 & $\mathrm{CH}_{2}$ rock & Dodecane & ++ & - & $+\uparrow$ \\
\hline 1033 & $\mathrm{CH}_{2}$ rock & Dodecane & + & - & - \\
\hline 1058 & C-C stretch & Mineral oil & ++ & + & + \\
\hline 1133 & $\begin{array}{c}\mathrm{C}-\mathrm{C} \text { asymmetric } \\
\text { stretch and } \mathrm{CH}_{2} \text { wag }\end{array}$ & $\begin{array}{l}\text { Dodecane, tetradecane, } \\
\text { crude oil, mineral oil }\end{array}$ & +++ & + & + \\
\hline 1297 & $\mathrm{CH}_{2}$ twist & $\begin{array}{c}\text { Dodecane, tetradecane, } \\
\text { crude oil }\end{array}$ & +++ & + & $+++\uparrow$ \\
\hline 1437 & $\begin{array}{l}\text { Symmetric } \mathrm{CH}_{2} \\
\text { scissors vibration }\end{array}$ & Crude oil & +++ & - & $+++\uparrow$ \\
\hline 1439 & $\mathrm{CH}_{2}$ bend & $\begin{array}{c}\text { Dodecane, tetradecane, } \\
\text { mineral oil }\end{array}$ & +++ & +++ & $+++\uparrow$ \\
\hline 1459 & $\begin{array}{c}\text { Antisymmetric } \mathrm{CH}_{2} \\
\text { scissors vibration }\end{array}$ & Crude oil & +++ & - & $+++\uparrow$ \\
\hline 723 & $\begin{array}{l}\text { Ring breathing } \\
\text { vibration }\end{array}$ & Bacterial nucleic acids & - & ++ & $+\downarrow$ \\
\hline 777 & $\begin{array}{l}\text { Ring breathing } \\
\text { vibration }\end{array}$ & Bacterial nucleic acids & - & ++ & $+\downarrow$ \\
\hline 1002 & $\begin{array}{l}\text { Benzene ring } \\
\text { breathing }\end{array}$ & Bacterial phenylalanine & - & +++ & $++\downarrow$ \\
\hline 1238 & l & Bacterial amino acids & - & + & $-\downarrow$ \\
\hline 1311 & l & Bacterial amino acids & - & + & $-\downarrow$ \\
\hline 1441 & $\begin{array}{l}\text { Deformations of } \\
\qquad \mathrm{CH}_{2}\end{array}$ & Bacterial glycine & - & +++ & $+++\uparrow$ \\
\hline 1663 & $\mathrm{C}=\mathrm{C}$ stretching & Bacterial proteins & - & +++ & +++ \\
\hline
\end{tabular}

“-” represents no peak identified; “+” represents weak peak; “++" represents medium peak; "+++" represents strong peak. Brown or green symbols indicate characteristic peaks belonging to alkanes and $A$. baylyi, respectively. Red or blue arrows represent the increases or decreases in respective Raman intensity of $A$. baylyi post-exposure to alkanes. 


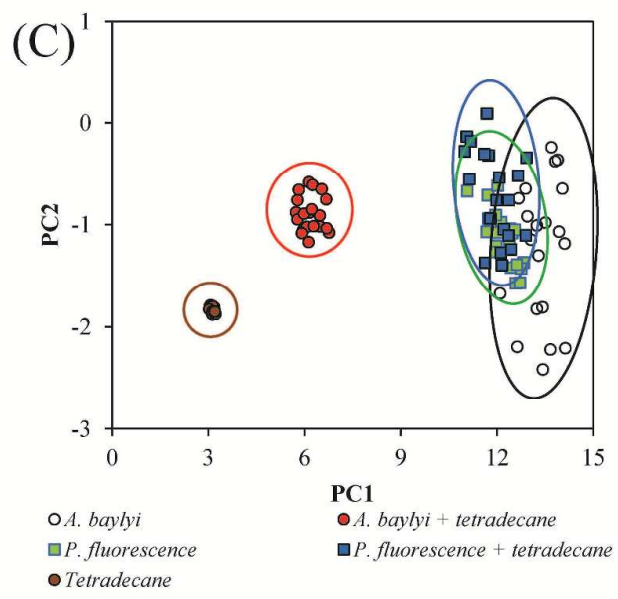

(B)

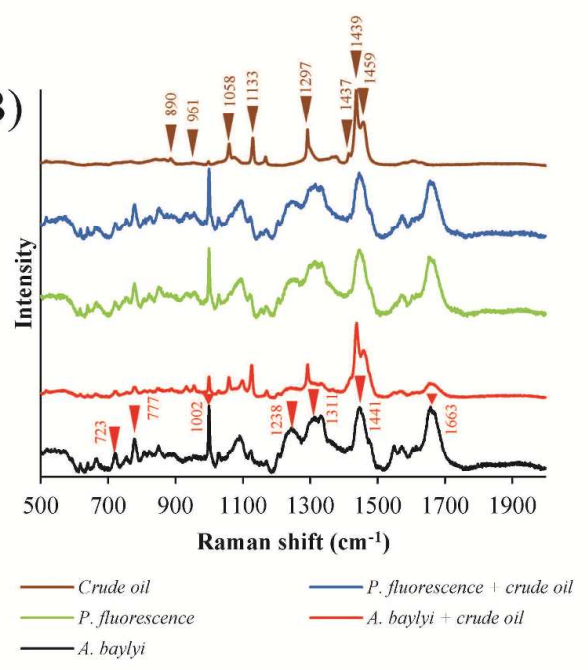

(D)

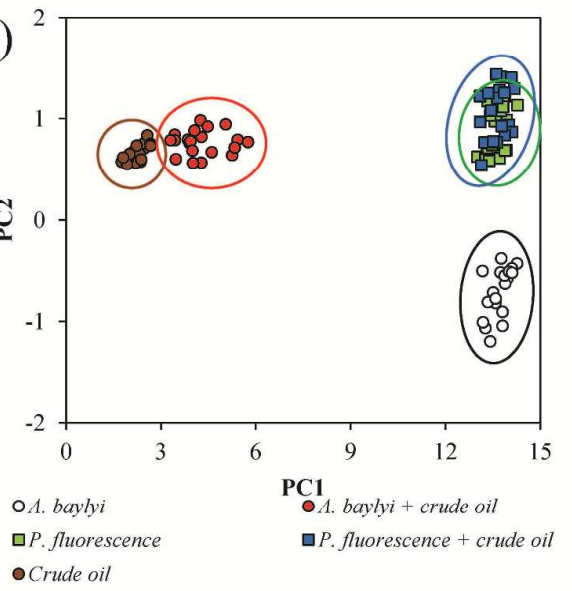

Figure 1. Raman spectra of $A$. baylyi and P. fluorescence, pre- and post-exposure to $100 \mathrm{mg} / \mathrm{L}$ tetradecane (A) or crude oil (B). PCA of Raman spectra shows the significant segregation of $A$. baylyi categories when exposed to $100 \mathrm{mg} / \mathrm{L}$ tetradecane (C) or crude oil (D) due to chemotaxis-related alkane affinity and accumulation, but not $P$. fluorescence. Twenty Raman spectra were randomly obtained per treatment.

The Raman spectra of original $A$. baylyi and $P$. fluorescence cells are similar, due to their close relationship to the order Pseudomonadales from genomic and proteomic analyses ${ }^{25,26,57}$. From Figure 1A, 1B and Table 1, both $777 \mathrm{~cm}^{-1}$ and $723 \mathrm{~cm}^{-1}$ bands refer to nucleic acids ${ }^{58}$. The band at $1441 \mathrm{~cm}^{-1}$ is assigned to glycine in bacterial cells ${ }^{40}$. Amino acids bands are also observed in the Raman spectra at $1238 \mathrm{~cm}^{-1}$ and $1311 \mathrm{~cm}^{-158}$.The $1663 \mathrm{~cm}^{-1}$ band represents protein and the $1002 \mathrm{~cm}^{-1}$ band points to 
phenylalanine. Post-exposure to tetradecane or crude oil, entirely different Raman spectra are identified for the two strains. The Raman spectra of $P$. fluorescence remain unchanged, explained by the fact that alkanes exhibit no chemo-attraction and are not accumulated in P. fluorescence. Accordingly, all the P. fluorescence cells fall into one category after PCA (Figure 1C and 1D) and are indistinguishable pre- and post-exposure to tetradecane or crude oil. The Raman spectra of A. baylyi exhibit significant alterations post-exposure to alkanes (Figure 1A, 1B and Table 1). Postexposure bacterial spectra are coupled with some key alkane bands. Two strong alkane bands, $1297 \mathrm{~cm}^{-1}$ ( $\mathrm{CH}_{2}$ twist) and $1439 \mathrm{~cm}^{-1}\left(\mathrm{CH}_{2}\right.$ bend), are observed in all Raman spectra of A. baylyi exposed to tetradecane or crude oil.

In dodecane treatment, the specific $961 \mathrm{~cm}^{-1}$ and $1033 \mathrm{~cm}^{-1}$ bands are attributed to $\mathrm{CH}_{2}$ rock (Table 1). The bands $1058 \mathrm{~cm}^{-1}\left(\mathrm{CH}_{2}\right.$ twist-rock) and $890 \mathrm{~cm}^{-1}(\mathrm{C}-\mathrm{C}$ stretch) only appear in A. baylyi treated with mineral oil (see ESI Figure S2D), and the bands $1060 \mathrm{~cm}^{-1}$ (ring breathing of benzene) and 1430-1470 $\mathrm{cm}^{-1}$ (symmetric and antisymmetric $\mathrm{CH}_{2}$ scissors vibrations) are found in the spectra of A. baylyi exposed to crude oil (Figure 1B). It is worth noting that both chemotaxis-related affinity and accumulation of alkane might contribute to the appearance of alkane characteristic bands, where alkane affinity significantly accelerates the access, accumulation and potential internalization of alkanes by A. baylyi and enhances Raman signals. PCA of Raman spectra (Figure 1C and 1D) further proves that alkane affinity and accumulation result in the significant differentiation of $A$. baylyi post-exposure to tetradecane or crude oil. The category comprising A. baylyi treated with tetradecane is very close to that of pure tetradecane, whereas the crude oil exposure leads to similarity between A. baylyi and crude oil. They are both significantly separated from the original A. baylyi group. The results show that the significant Raman spectral alterations are caused by the alkane affinity and accumulation of A. baylyi. Moreover, the strong terminal methyl $\mathrm{CH}_{3}$ rock $\left(890 \mathrm{~cm}^{-1}\right)$ is only found in A. baylyi spectra post-exposed to tetradecane, readily discriminated from those in crude oil treatment. Therefore, our findings reveal that chemotaxis-related alkane affinity contributes to the adhesion of alkane molecules onto the membrane of A. baylyi cells, allowing further alkane accumulation or cellular internalization. Raman spectral alterations highlight such chemotaxis-related affinity and accumulation, and even distinguish the different chemo-attracted molecules quickly and with high reproducibility. 
To test the specificity of the hydrocarbons affinity and accumulation in A. baylyi, various hydrocarbon molecules were tested, including pure alkanes (dodecane or tetradecane), alkane mixtures (mineral oil or crude oil), MAHs (toluene or xylene) and PAHs (naphthalene or phenanthrene). Raman spectral alterations are only found for pure alkanes or alkane mixtures (Figure 2B, see ESI Figure S2). PCA differentiation illustrates that the categories for post-exposure to MAHs or PAHs cocluster due to significant Raman bands for benzene ring breathing peaks at $1001 \mathrm{~cm}^{-1}$ and $1027 \mathrm{~cm}^{-1}$ for toluene or xylene, $760 \mathrm{~cm}^{-1}$ for naphthalene and $705 \mathrm{~cm}^{-1}$ for phenanthrene (see ESI Figure S2) ${ }^{59-61}$. The category for crude oil is located between pure alkanes and MAHs/PAHs, because it consists of various hydrocarbons, including alkanes, MAHs and PAHs. As a by-product from crude oil distillation, mineral oil is a mixture of n-alkanes and located very close to the category for pure alkanes ${ }^{62}$. Postexposure to MAHs (toluene, xylene) or PAHs (phenanthrene and naphthalene), PCA of A. baylyi fails to segregate these categories from unexposed comparator cells. The results were consistent with hydrocarbon capillary assay (Figure 2A) in which the accumulated 16S rRNA copy numbers of $A$. baylyi were much higher in oil mixtures and pure alkanes treatments than those in PAHs and MAHs treatments, indicating that A. baylyi has chemo-attraction towards neither MAHs nor PAHs, which has been proved previously ${ }^{16,24}$. After PCA, the categories for A. baylyi exposed to pure alkane or alkane mixtures co-cluster with those of the pure chemicals respectively, and are completely separated from the unexposed comparator cells. These results prove that the chemotactic association between alkane and A. baylyi is the key factor in altering Raman spectra. Such chemotaxis-related affinity is specific to alkanes and helps further alkane accumulation or internalization within A. baylyi cells, resulting in significant spectral alterations compared to those induced by other hydrophobic molecules (MAHs or PAHs). Thus, we conclude from the Raman spectral discrimination that the alterations in A. baylyi exposed to mineral oil or crude oil is attributable to chemotaxis-related affinity towards alkanes; these are the main components of mineral oil and crude oil.

Previous research has examined the mechanisms of alkane chemotaxis. In the presence of alkanes, OmpS is most likely the first sensor protein to transmit signals back to bacterial cells ${ }^{63}$. The chemotactic signals are stimulated by a complex protein 
system that is comprised of coupling CheW and methyl-accepting chemotaxis (MCP) to the histidine kinase $\mathrm{CheA}^{64-66}$. It is also reported that the MCP is captured firmly in this protein complex, whereas a substantial part of CheW and CheA is free in cells ${ }^{67}$. The signals from OmsP are likely received by the MCP protein embedded on CheW/CheA complex. The coupling protein CheW2 is found in Alcanivorax dieselole $i$ as the chemotaxis complex only induced by long-chain alkanes ${ }^{68-71}$. Hence, bacterial chemotaxis towards alkanes is hypothesized to exhibit high specificity, and the chemotaxis-related alkane affinity and accumulation therefore follows the same behaviour. Our results provide direct evidence that Raman spectral alterations of $A$. baylyi are only observed for linear n-alkanes, not MAHs or PAHs.
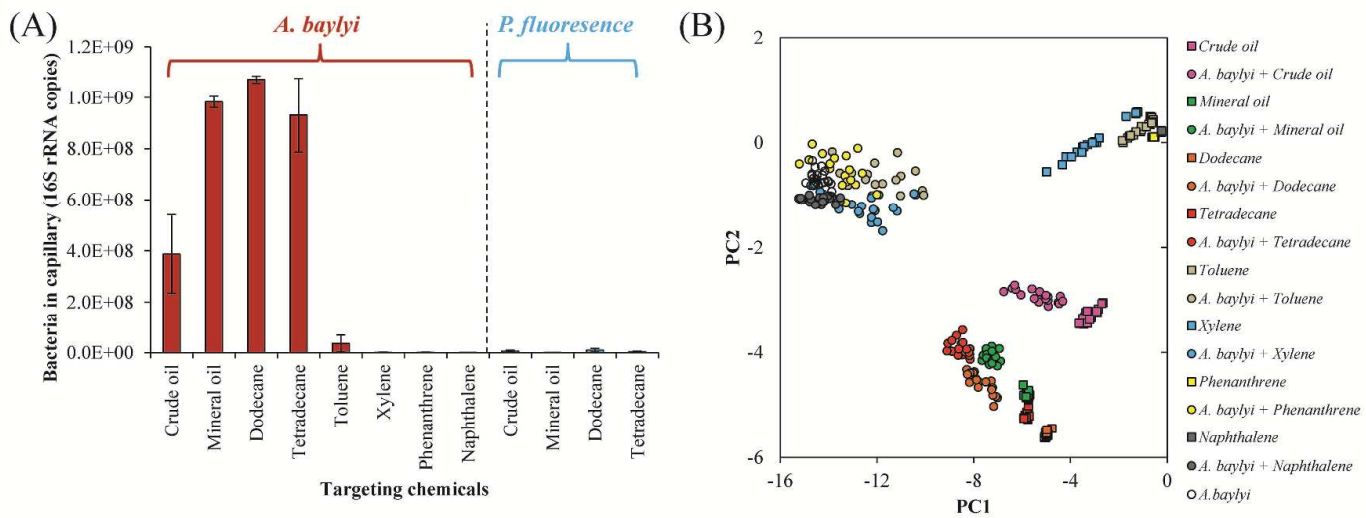

Figure 2. (A) Validation of alkane chemotaxis via capillary assay. High amount of bacterial $16 \mathrm{~S}$ rRNA in capillary indicates significant chemotaxis of A. baylyi (red bar) towards dodecane, tetradecane, mineral oil or crude oil, whereas $P$. fluorescence (blue bar) does not show chemotaxis to these hydrocarbons. (B) Raman spectral segregation by PCA of $A$. baylyi exposed to different hydrocarbons. The tested chemicals with alkane-chemotaxis effect include: dodecane, tetradecane, mineral oil or crude oil. The tested chemicals without chemotaxis effect were: monocyclic aromatic hydrocarbons (toluene or xylene) and polycyclic aromatic hydrocarbons (naphthalene or phenanthrene). Twenty Raman spectra were randomly obtained per treatment. 


\section{Time-dependent Raman spectra alteration}

To identify the optimal exposure time of $A$. baylyi to alkanes, bacterial cells were treated with $100 \mathrm{mg} / \mathrm{L}$ tetradecane or crude oil for $0.5,1.0,3.0$ or $5.0 \mathrm{~h}$. The results from PCA (Figure 3) indicate that the Raman spectral alterations of A. baylyi alkane association are time-dependent. With the sensitive chemotactic affinity of $A$. baylyi towards alkanes, significant spectral alterations are observed within $0.5 \mathrm{~h}$ for both tetradecane or crude oil, and the most discrimination is at $1.0 \mathrm{~h}$. Interestingly, after 0.5 $\mathrm{h}$ exposure, the cluster of $A$. baylyi cells treated with tetradecane exhibits most discrimination compared to the untreated category (Figure 3A) versus cells exposed to crude oil (Figure 3B). Thus affinity of tetradecane appears stronger than crude oil. This is very likely explained by the complex composition of crude oil, which consists of alkanes, MAHs and PAHs. On the surface of crude oil droplets, all these molecules are evenly distributed, leaving fewer active sites of chemo-attractive alkanes for the effective recognition by the MCP of A. baylyi. The diverse hydrophobic components in crude oil droplets reduce alkanes bioavailability, challenge the access of bacteria to alkane molecules ${ }^{72}$ and slow down alkanes utilization by $A$. baylyi ${ }^{73}$. The accessibility of A. baylyi to tetradecane is therefore faster and such stronger adhesion to pure alkane droplets has been reported ${ }^{74-76}$.
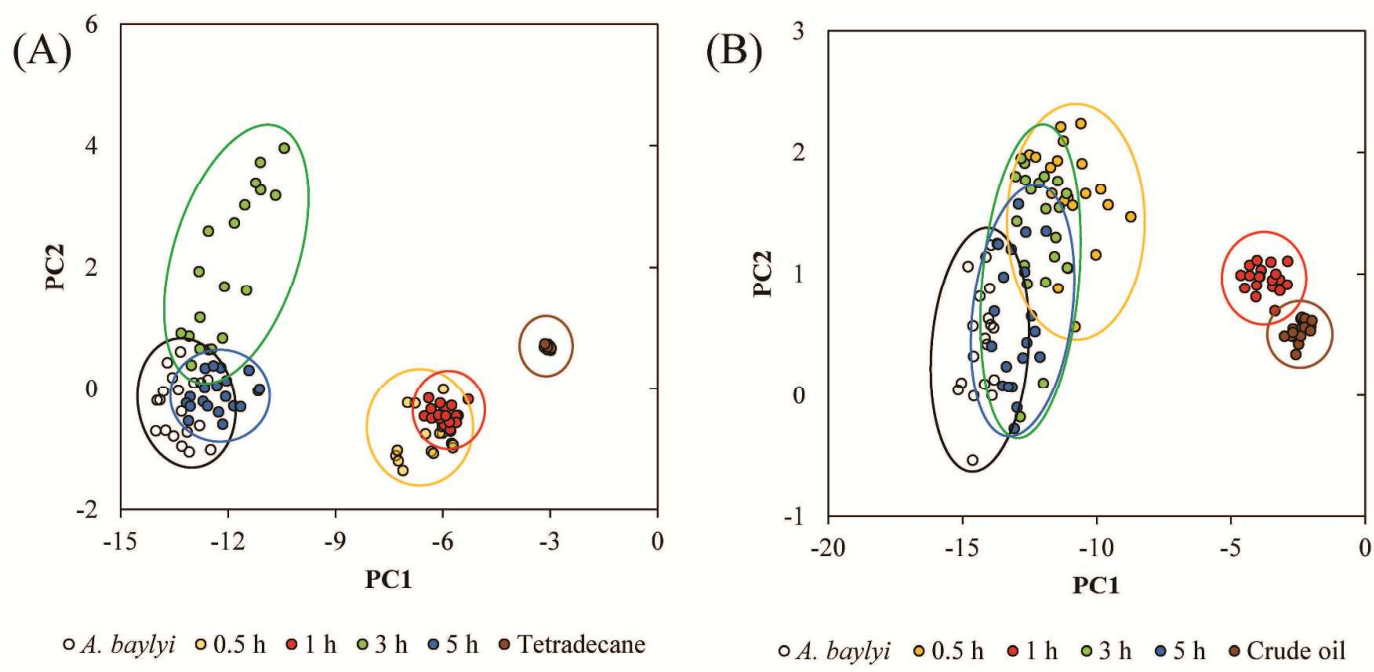

Figure 3. PCA segregation of A. baylyi Raman spectra against exposure time in tetradecane (A) and crude oil (B) treatments. Twenty Raman spectra were randomly obtained per treatment. 
A. baylyi has the alkane monooxygenese encoding alkM gene and can metabolize n-alkanes ${ }^{16}$. The activation of alkM is reported to occur within 30 min post-exposure to alkanes, when significant alkane degradation occurs ${ }^{66,74}$. The alkane molecules accumulated on cell membrane or internalized inside A. baylyi cells were therefore hypothesized to be rapidly consumed. Our test on residual hydrocarbon concentrations (see ESI Figure S3) proves this hypothesis that the dramatic alkane degradation was only observed within the first 1 hour and its concentration remained stable thereafter. Thus, the amount of alkanes captured and accumulated by A. baylyi cells peaked at 1 hour and resulted in the most discrimination in Raman spectral fingerprints (Figure 3). This explains the diminishing spectral alterations after 1-h exposure. As a consequence, the Raman spectral categories of $0.5,3$ and $5 \mathrm{~h}$ exposure are clustered close to the original A. baylyi category in either tetradecane or crude oil treatments (Figure 3, see ESI Figure S4). Thus, the highest alkane affinity and accumulation of alkanes was at $1.0 \mathrm{~h}$, at which time the strongest spectral alterations are found. Therefore, 1-h exposure was applied for all the subsequent experiments. Compared to the conventional hydrocarbon chemotaxis capillary assay (see ESI Figure S5) in which the maximum bacterial enrichment was $0.5 \mathrm{~h}$ for crude oil and 3 $\mathrm{h}$ for tetradecane, our Raman assay had different response time $(1.0 \mathrm{~h}$ for both crude oil and tetradecane). It might be explained by the different chemotaxis-related behaviour quantified by the two methods. The chemotaxis capillary assay measures the chemotaxis-driven bacterial migration in alkane gradients, whereas the Raman spectral alteration represents the chemotaxis-related affinity and accumulation of alkane molecules on A. baylyi cells. It is worth highlighting that the Raman assay is a faster and higher throughput interrogation of specific chemical affinity and accumulation than the conventional capillary assay. Though the chemotactic response is around 1 hour in both methods, the Raman assay takes only $20 \mathrm{~min}$ for wash/dry and 1-2 min spectral measurement, much less than that required in determining bacterial enrichment by the capillary assay (3-4 hours by qPCR or 18 hours by plate counting). Additionally, the attractant only needs to be mixed together with targeting bacterial suspension, easier than the plunge and transfer of attractant medium in numerous capillaries in the conventional assay, allowing high-throughput detection for many chemicals in 96-well plates. 
Quantification of alkane affinity and accumulation by Raman spectral alterations

Raman spectral alterations of A. baylyi chemotaxis-related affinity and accumulation towards alkane allow evaluation of the sensitivity of alkane affinity and to quantify alkane concentration in aquatic phase. Figure 4 illustrates the PCA categorisation of $A$. baylyi Raman spectra following different exposures (1, 2, 5, 10, 20, 50, $100 \mathrm{mg} / \mathrm{L})$ of dodecane, tetradecane, mineral oil or crude oil, respectively. After 1-h exposure to the targeted alkane molecules or mixtures, all the characteristic peaks of $A$. baylyi remained the same, and the new altered peaks originated from alkanes (see ESI Figure S6). The intensity of alkane characteristic peaks increased with increasing dodecane (or tetradecane) exposure, especially for the band at $1297 \mathrm{~cm}^{-1}$ which is annotated to $\mathrm{CH}_{2}$ twist and dominates in alkane molecules. The Raman peak of $\mathrm{CH}_{2}$ bend at 1493 $\mathrm{cm}^{-1}$ was positively related to the alkane concentrations. The terminal methyl $\mathrm{CH}_{3}$ Raman signal of alkane at $890 \mathrm{~cm}^{-1}$ was detected when the concentrations of dodecane and tetradecane was $20 \mathrm{mg} / \mathrm{L}$ or higher. Besides pure alkanes, similar Raman spectral alterations were found for treatments with alkane mixtures (mineral oil or crude oil; Figure 4C and 4D). Spectral alternations of A. baylyi are separated post-exposure to different concentrations of mineral oil or crude oil. The key altered peaks of mineral oil and crude oil include the $1297 \mathrm{~cm}^{-1}$ and $1439 \mathrm{~cm}^{-1}$ bands representing $\mathrm{CH}_{2}$ twist and bend, respectively (see ESI Figure S7). The consistent alteration $\left(1297 \mathrm{~cm}^{-1}\right.$ and $\left.1439 \mathrm{~cm}^{-1}\right)$ in all bacterial spectra exposed to alkanes and alkane mixtures prove that $A$. baylyi has specific affinity towards alkane molecules ${ }^{16,77}$.

The results of LDA and dispersion indicator $\left(D_{I}\right)$ scores plots show the specific chemotaxis-related affinity and accumulation of $A$. baylyi towards different alkanes (Figure 5). There is no significant discrimination between the categories of A. baylyi exposed to 0,1 or $2 \mathrm{mg} / \mathrm{L}$ dodecane (Figure $5 \mathrm{~A}$ ), while $A$. baylyi treated with $1 \mathrm{mg} / \mathrm{L}$ tetradecane is completely segregated from the negative control $(0 \mathrm{mg} / \mathrm{L}$, Figure $5 \mathrm{~B})$. This indicates that the limit of alkane detection via Raman microspectroscopy is 5 $\mathrm{mg} / \mathrm{L}$ for dodecane and $1 \mathrm{mg} / \mathrm{L}$ for tetradecane. Although A. baylyi can respond to alkane levels as low as $0.1 \mathrm{mg} / \mathrm{L}$ by bioreporter data ${ }^{16}$, the lower sensitivity of Raman spectra is possibly attributed to the weak signal of accumulated or internalized alkane molecules. At low alkane concentrations, only partial MCP recognizes and captures 
alkane molecules. Similar behaviour is observed for alkane mixtures, with a limit of detection of $1 \mathrm{mg} / \mathrm{L}$ for mineral oil and $2 \mathrm{mg} / \mathrm{L}$ for crude oil.
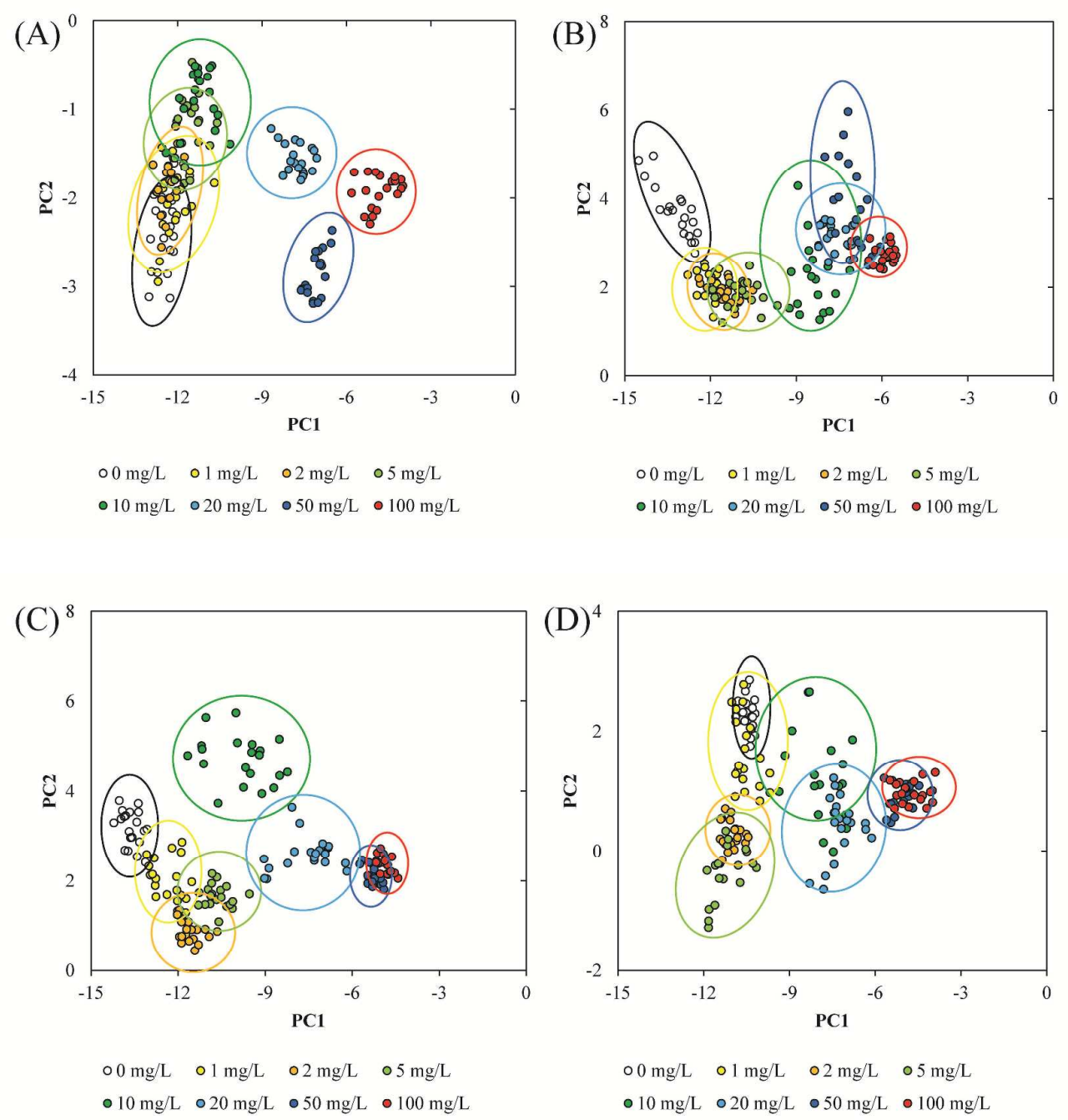

Figure 4. PCA segregation of A. baylyi Raman spectra at different concentrations of dodecane (A), tetradecane (B), mineral oil (C) or crude oil (D). For each treatment, twenty replicates were performed.

With increasing alkane levels, the more alkane molecules accumulate on or inside A. baylyi cells and consequently result in increasing alkane characteristic peaks and more significant Raman spectral alterations. Above the limit of detection, all the alkanes or alkane mixtures gave rise to a semi-log linear regression relationship with $D_{I}$ (see ESI Figure S8). The semi-log linear slope of pure alkanes and alkane mixtures followed the order: mineral oil $(0.583)>$ crude oil $(0.532)>$ tetradecane $(0.478)>$ 
dodecane (0.399). The quantification range was from $1 \mathrm{mg} / \mathrm{L}$ to $100 \mathrm{mg} / \mathrm{L}$ for tetradecane and mineral oil, $2 \mathrm{mg} / \mathrm{L}$ to $100 \mathrm{mg} / \mathrm{L}$ for crude oil and $5 \mathrm{mg} / \mathrm{L}$ to 100 $\mathrm{mg} / \mathrm{L}$ for dodecane. The values of semi-log linear slopes were consistent with the limits of detection for all the pure alkanes and alkane mixtures. It indicates the selectivity of alkane affinity and accumulation in A. baylyi varies with different carbon chain lengths. For instance, the cheY1 and cheY2 genes in Alcanivorax dieselolei are triggered by $\mathrm{C}_{8}-\mathrm{C}_{24}$ n-alkanes and alkanes longer than $\mathrm{C}_{24}$, respectively $^{71}$. In this study, A. baylyi had higher affinity towards and subsequently accumulation of tetradecane than dodecane, due to a lower limit of detection $(1 \mathrm{mg} / \mathrm{L}$ vs. $5 \mathrm{mg} / \mathrm{L})$ and higher slopes (0.478 vs. 0.399). The expression of genes related to alkane affinity and internalization in A. baylyi is therefore dependent on alkane carbon chain length, and it can be evaluated and quantified by Raman spectra.
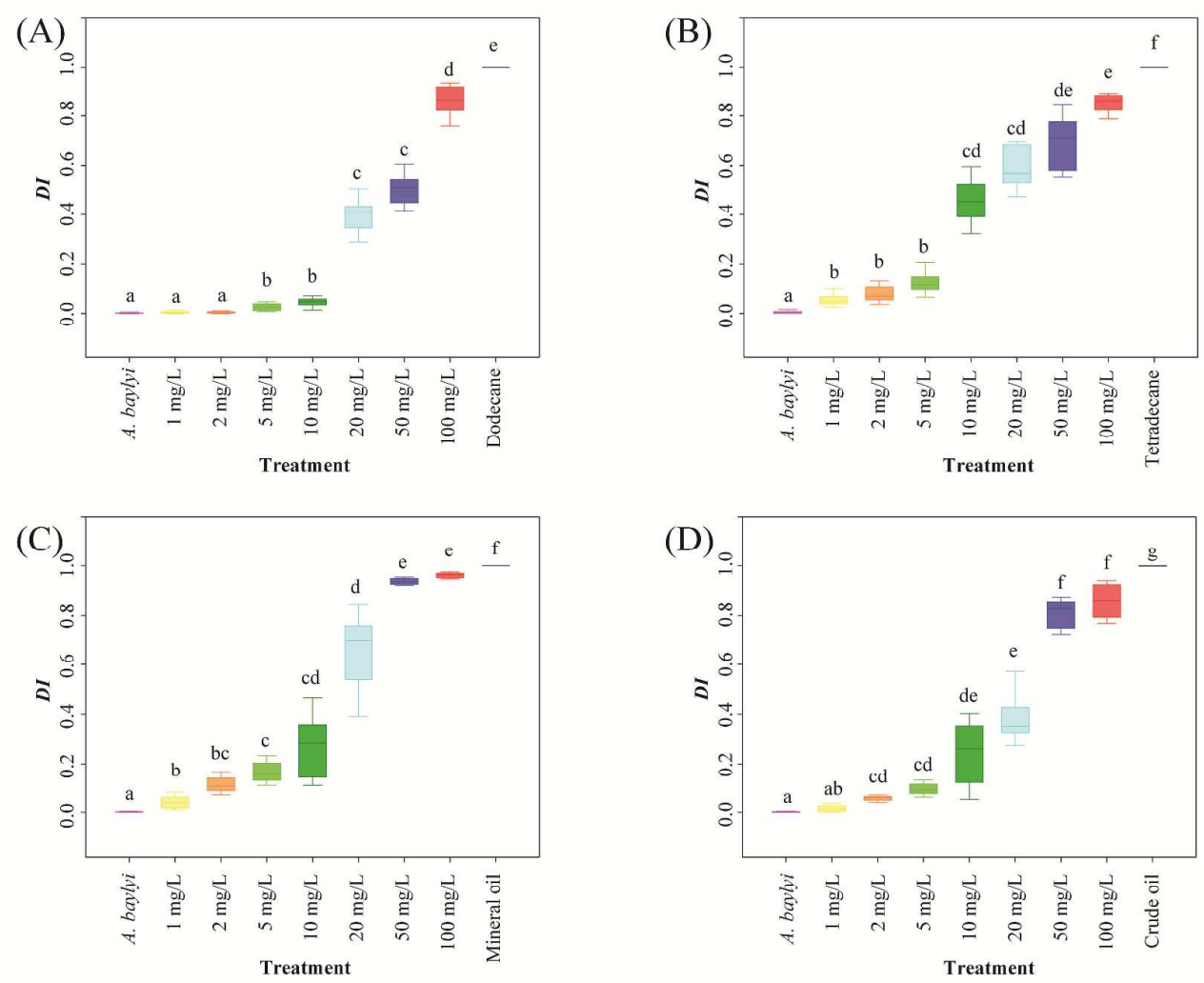

Figure 5. $D_{I}$ scores plots of $A$. baylyi Raman spectra following different concentrations of dodecane (A), tetradecane (B), mineral oil (C) or crude oil (D). For each treatment, twenty replicates were performed. Boxes with different letters indicated a significant difference based on $\operatorname{LSD}(P$-value $<0.05)$. 
The differing spectral alteration in mineral oil and crude oil treatments suggests that A. baylyi exhibits the stronger sensitivity of chemotaxis-related affinity and accumulation for mineral oil than crude oil. Considering the composition of the two alkane mixtures, mineral oil is fully composed of alkanes with different carbon chain lengths, whereas alkanes only account for $20-25 \%$ of the total weight of crude oil. Not all the molecules of crude oil can be chemotactically sensed by A. baylyi cells, consequently resulting in the lowest affinity and accumulation. More interestingly from linear slopes, both tetradecane and dodecane have lower affinity than mineral oil and crude oil. From the discussion above, the MCP recognition and expression is dependent on the carbon chain length of alkanes. For instance, the expression of alkM alkane monooxygenese gene in A. baylyi is more highly induced by dodecane than tetradecane, suggesting that the alkR encoding AraC-XylS-like transcriptional regulators has unique sensitivity towards alkanes with different carbon chain length $^{29,36,75,78}$. Thus, A. baylyi is hypothesized to have higher affinity towards some other alkane molecules with different carbon chain lengths in mineral oil or crude oil, and Raman spectral alterations of $A$. baylyi are enhanced post-exposure to mineral oil and crude oil.

Though the current detection limit of Raman assay is still above the natural hydrocarbon contamination level (0.1-1 mg/L) and does not meet with the monitoring requirement for environmental hydrocarbons, it can be improved by optimizing attractant medium, such as $\mathrm{pH}$ and ionic strength. Meanwhile, alkane affinity and accumulation has been extensively investigated, but there is a lack of effective approaches to quantify its sensitivity, which is one of restriction factors in bioremediation at oil contaminated sites. Our results successfully prove the concept that Raman spectral alterations provide a rapid, non-destructive tool towards understanding alkane affinity and accumulation. More research is required to address the mechanisms of chemotaxis-related alkane affinity and accumulation to a wider range of alkanes with differing carbon chain lengths.

\section{Conclusion}

Herein, we developed a novel alkane quantification method based on chemotaxisrelated alkane affinity and accumulation of $A$. baylyi and Raman spectral alterations. To the best of our knowledge, this is the first study to show that Raman microspectroscopy can be used to identify and quantify the microbial chemotaxis- 
related affinity and accumulation of alkanes. It opens up new possibilities for the rapid biological detection of aquatic alkane concentrations with natural microorganisms, instead of gene-modified bioreporters. Importantly, alkane chemoaffinity facilitates bacterial access to alkanes, and internalization determines alkane metabolism inside bacterial cells, both playing a key role in alkane degradation in the natural environment. The effective quantification of alkane affinity and accumulation via Raman spectra contributes to new insights into the microbial utilization of alkanes. This technique is also feasible to identify and characterize bacterial affinity and accumulation towards other molecules.

\section{Acknowledgement}

The authors would like to thank National Natural Science Foundation of China (No. 41301331) and Lancaster University FST research grant for financial support. Hanbing Li is supported by China Scholarship Council (CSC).

\section{Supporting Information}

Dispersion indicator model; Chemotaxis of A. baylyi and P. fluorescence to mineral oil, tetradecane, xylene and phenanthrene (Figure S1); Raman spectra of A. baylyi exposure to different hydrocarbons (Figure S2); Relationship between dispersion indicator of Raman spectra and residual hydrocarbon contents (Figure S3); Raman spectra of A. baylyi against exposure time (Figure S4); Alkane chemotaxis against time via chemotaxis capillary assay (Figure S5); Raman spectra of A. baylyi exposure to different concentrations of dodecane and tetradecane (Figure S6); Raman spectra of A. baylyi exposure to different concentrations of mineral oil and crude oil (Figure S7); Semi-log linear regression of the n-alkane concentrations and dispersion indicator within the quantification range (Figure S8). 


\section{Reference}

(1) Bence, A. E.; Kvenvolden, K. A.; Kennicutt, M. C. Org. Geochem. 1996, 24, 7-42.

(2) Bragg, J. R.; Prince, R. C.; Harner, E. J.; Atlas, R. M. Nature 1994, 368, 413-418.

(3) Camilli, R.; Reddy, C. M.; Yoerger, D. R.; Van Mooy, B. A. S.; Jakuba, M. V.; Kinsey, J. C.; McIntyre, C. P.; Sylva, S. P.; Maloney, J. V. Science 2010, 330, 201204.

(4) Zhang, D.; Ding, A.; Cui, S.; Hu, C.; Thornton, S. F.; Dou, J.; Sun, Y.; Huang, W. E. Water Res. 2013, 47, 1191-1200.

(5) Peterson, C. H.; Rice, S. D.; Short, J. W.; Esler, D.; Bodkin, J. L.; Ballachey, B. E.; Irons, D. B. Science 2003, 302, 2082-2086.

(6) Piatt, J. F.; Lensink, C. J.; Butler, W.; Kendziorek, M.; Nysewander, D. R. Auk 1990, 107, 387-397.

(7) USEPA. 1998.

(8) USEPA. 1998.

(9) USEPA. 1999.

(10) Zhou, Z.; Guo, L.; Shiller, A. M.; Lohrenz, S. E.; Asper, V. L.; Osburn, C. L. Mar. Chem. 2013, 148, 10-21.

(11) Wang, C.; Shi, X.; Li, W.; Wang, L.; Zhang, J.; Yang, C.; Wang, Z. Mar. Pollut. Bull. 2016.

(12) Lay-Ekuakille, A.; Palamara, I.; Caratelli, D.; Morabito, F. C. Rev. Sci. Instrum. 2013, 84, 015103.

(13) Krupcik, J.; Gorovenko, R.; Spanik, I.; Bockova, I.; Sandra, P.; Armstrong, D. W. J. Chromatogr. A 2013, 1301, 225-36.

(14) Liu, W.; Chen, J.; Lin, X.; Fan, Y.; Tao, S. Environ. Pollut. 2007, 146, 470-7.

(15) D'Auria, M.; Racioppi, R.; Velluzzi, V. J. Chromatogr. Sci. 2008, 46, 339-344.

(16) Zhang, D.; He, Y.; Wang, Y.; Wang, H.; Wu, L.; Aries, E.; Huang, W. E. Microbial Biotech. 2012, 5, 87-97.

(17) Sticher, P.; Jaspers, M. C. M.; Stemmler, K.; Harms, H.; Zehnder, A. J. B.; vanderMeer, J. R. Appl. Environ. Microbiol. 1997, 63, 4053-4060.

(18) Wang, W.; Shao, Z. Front. Microbiol. 2013, 4.

(19) Parales, R. E.; Harwood, C. S. Curr. Opin. Microbiol. 2002, 5, 266-273.

(20) Smits, T. H. M.; Witholt, B.; van Beilen, J. B. Anton. Leeuw. Int. J. G. 2003, 84, 193-200.

(21) van Beilen, J. B.; Panke, S.; Lucchini, S.; Franchini, A. G.; Rothlisberger, M.; Witholt, B. Microbiol. SGM 2001, 147, 1621-1630.

(22) Lanfranconi, M. P.; Alvarex, H. M.; Studdert, C. A. Environ. Microbiol. 2003, 5, 1002-1008.

(23) Lai, Q.; Li, W.; Shao, Z. J. Bacteriol. 2012, 194, 6674-6674.

(24) Huang, W. E.; Singer, A. C.; Spiers, A. J.; Preston, G. M.; Whiteley, A. S. Environ Microbiol 2008, 10, 1668-80.

(25) Vaneechoutte, M.; Young, D. M.; Ornston, L. N.; De Baere, T.; Nemec, A.; Van Der Reijden, T.; Carr, E.; Tjernberg, I.; Dijkshoorn, L. Appl. Environ. Microbiol. 2006, 72, 932-936.

(26) Young, D. M.; Parke, D.; Ornston, L. N. Annu. Rev. Microbiol. 2005, 59, 519551.

(27) Foster, J. Oxygenases. Academic, New York 1962, 241-261.

(28) Rosenberg, E. Trends Biotechnol. 1993, 11, 419-424.

(29) Wentzel, A.; Ellingsen, T. E.; Kotlar, H.-K.; Zotchev, S. B.; Throne-Holst, M. Appl. Microbiol. Biotechnol. 2007, 76, 1209-1221. 
(30) Boulton, C.; Ratledge, C. Top. Enzyme Ferment. Biotechnol. 1984, 9, 11-77.

(31) Haferburg, D.; Hommel, R.; Claus, R.; Kleber, H.-P. In Bioproducts; Springer, 1986, pp 53-93.

(32) Singer, M.; Finnerty, W. 1984.

(33) Efrima, S.; Zeiri, L. J. Raman Spectrosc. 2009, 40, 277-288.

(34) Efrima, S.; Bronk, B. J. Phys. Chem. B 1998, 102, 5947-5950.

(35) Guzelian, A. A.; Sylvia, J. M.; Janni, J. A.; Clauson, S. L.; Spencer, K. M. In Environmental and Industrial Sensing; International Society for Optics and Photonics, 2002, pp 182-192.

(36) Wang, Y.; Ravindranath, S.; Irudayaraj, J. Anal. Bioanal. Chem. 2011, 399, 1271-1278.

(37) Zhou, H.; Yang, D.; Ivleva, N. P.; Mircescu, N. E.; Schubert, S. r.; Niessner, R.; Wieser, A.; Haisch, C. Anal. Chem. 2015, 87, 6553-6561.

(38) Cheng, H.-W.; Huan, S.-Y.; Yu, R.-Q. The Analyst 2012, 137, 3601-3608.

(39) Cheng, H.-W.; Luo, W.-Q.; Wen, G.-L.; Huan, S.-Y.; Shen, G.-L.; Yu, R.-Q. The Analyst 2010, 135, 2993-3001.

(40) Cui, L.; Chen, P.; Chen, S.; Yuan, Z.; Yu, C.; Ren, B.; Zhang, K. Anal. Chem. 2013, 85, 5436-43.

(41) Liu, Y.; He, L.; Mustapha, A.; Li, H.; Hu, Z.; Lin, M. J. Appl. Microbiol. 2009, 107, 1193-1201.

(42) Schuster, K. C.; Reese, I.; Urlaub, E.; Gapes, J. R.; Lendl, B. Anal. Chem. 2000, $72,5529-5534$.

(43) Kearns, D. B. Nat. Rev. Microbiol. 2010, 8, 634-44.

(44) Berg, H. C.; Turner, L. Biophys. J. 1990, 58, 919-930.

(45) Block, S. M.; Segall, J. E.; Berg, H. C. J. Bacteriol. 1983, 154, 312-323.

(46) Shi, L. Z.; Nascimento, J.; Chandsawangbhuwana, C.; Berns, M. W.; Botvinick, E. L. Microsc Res Tech 2006, 69, 894-902.

(47) Adler, J. Microbiology 1973, 74, 77-91.

(48) Wang, X.; Zhao, X.; Li, H.; Jia, J.; Liu, Y.; Ejenavi, O.; Ding, A.; Sun, Y.; Zhang, D. Res. Microbiol. 2016, DOI: 10.1016/j.resmic.2016.07.004.

(49) Cui, L.; Butler, H. J.; Martin-Hirsch, P. L.; Martin, F. L. Anal. Methods 2016, 8, 481-487.

(50) Trevisan, J.; Angelov, P. P.; Scott, A. D.; Carmichael, P. L.; Martin, F. L. Bioinformatics 2013, 29, 1095-1097.

(51) Butler, H. J.; Ashton, L.; Bird, B.; Cinque, G.; Curtis, K.; Dorney, J.; EsmondeWhite, K.; Fullwood, N. J.; Gardner, B.; Martin-Hirsch, P. L.; Walsh, M. J.; McAinsh, M. R.; Stone, N.; Martin, F. L. Nat. Protoc. 2016, 11, 664-687.

(52) Mao, H.; Cremer, P. S.; Manson, M. D. Proc. Natl. Acad. Sci. U. S. A. 2003, 100, 5449-54.

(53) Mizushima, S.-i.; Simanouti, T. J. Am. Chem. Soc. 1949, 71, 1320-1324.

(54) Kalyanasundaram, K.; Thomas, J. J. Phys. Chem. 1976, 80, 1462-1473.

(55) Graham, S. F.; Haughey, S. A.; Ervin, R. M.; Cancouët, E.; Bell, S.; Elliott, C. T. Food Chem. 2012, 132, 1614-1619.

(56) Orange, D.; Knittle, E.; Farber, D.; Williams, Q. Geol. Soc. Spec. Pub. 1996, 5, 65-81.

(57) Barbe, V.; Vallenet, D.; Fonknechten, N.; Kreimeyer, A.; Oztas, S.; Labarre, L.; Cruveiller, S.; Robert, C.; Duprat, S.; Wincker, P. Nucleic Acids Res. 2004, 32, 57665779 .

(58) De Gelder, J.; De Gussem, K.; Vandenabeele, P.; Moens, L. J. Raman Spectrosc. 2007, 38, 1133-1147. 
(59) Cloutis, E.; Szymanski, P.; Applin, D.; Goltz, D. Icarus 2016, 274, 211-230.

(60) Konradi, J.; Singh, A. K.; Materny, A. Phys. Chem. Chem. Phys. 2005, 7, 3574-9.

(61) Biedermann, M.; Grob, K. J. Chromatogr. A 2012, 1255, 56-75.

(62) Tarnow, P.; Hutzler, C.; Grabiger, S.; Schon, K.; Tralau, T.; Luch, A. PLoS One 2016, 11, e0147239.

(63) Wang, S.-K.; Wang, F.; Hu, Y.-R.; Stiles, A. R.; Guo, C.; Liu, C.-Z. ACS Appl. Mater. Interfaces 2014, 6, 109-115.

(64) Briegel, A.; Li, X.; Bilwes, A. M.; Hughes, K. T.; Jensen, G. J.; Crane, B. R. Proc. Natl. Acad. Sci. U. S. A. 2012, 109, 3766-3771.

(65) Hazelbauer, G. L.; Falke, J. J.; Parkinson, J. S. Trends Biochem. Sci. 2008, 33, 919.

(66) Xu, L.; Guo, C.; Wang, F.; Zheng, S.; Liu, C.-Z. Bioresour. Technol. 2011, 102, 10047-10051.

(67) Liu, J.; Hu, B.; Morado, D. R.; Jani, S.; Manson, M. D.; Margolin, W. Proc. Natl. Acad. Sci. U. S. A. 2012, 109, E1481-8.

(68) Lanfranconi, M. P.; Alvarez, H. M.; Studdert, C. A. Environ. Microbiol. 2003, 5, 1002-1008.

(69) Smits, T. H.; Witholt, B.; van Beilen, J. B. Anton. Leeuw. Int. J. G. 2003, 84, 193-200.

(70) Sourjik, V.; Armitage, J. P. EMBO J. 2010, 29, 2724-2733.

(71) Wang, W.; Shao, Z. Nat. Commun. 2014, 5.

(72) Prince, R. C.; McFarlin, K. M.; Butler, J. D.; Febbo, E. J.; Wang, F. C.; Nedwed, T. J. Chemosphere 2013, 90, 521-6.

(73) Lal, B.; Khanna, S. J. Appl. Bacteriol. 1996, 81, 355-362.

(74) Maeng, J. H.; Sakai, Y.; Tani, Y.; Kato, N. J. Bacteriol. 1996, 178, 3695-3700.

(75) Ratajczak, A.; Geißdörfer, W.; Hillen, W. J. Bacteriol. 1998, 180, 5822-5827.

(76) Throne-Holst, M.; Wentzel, A.; Ellingsen, T. E.; Kotlar, H.-K.; Zotchev, S. B. Appl. Environ. Microbiol. 2007, 73, 3327-3332.

(77) Tanaka, D.; Takashima, M.; Mizuta, A.; Tanaka, S.; Sakatoku, A.; Nishikawa, A.; Osawa, T.; Noguchi, M.; Aizawa, S.-I.; Nakamura, S. Curr. Microbiol. 2010, 60, 203209.

(78) Wang, X. B.; Nie, Y.; Tang, Y. Q.; Wu, G.; Wu, X. L. Appl. Environ. Microbiol. 2013, 79, 400-2. 
Table of Content Graphic

4

6

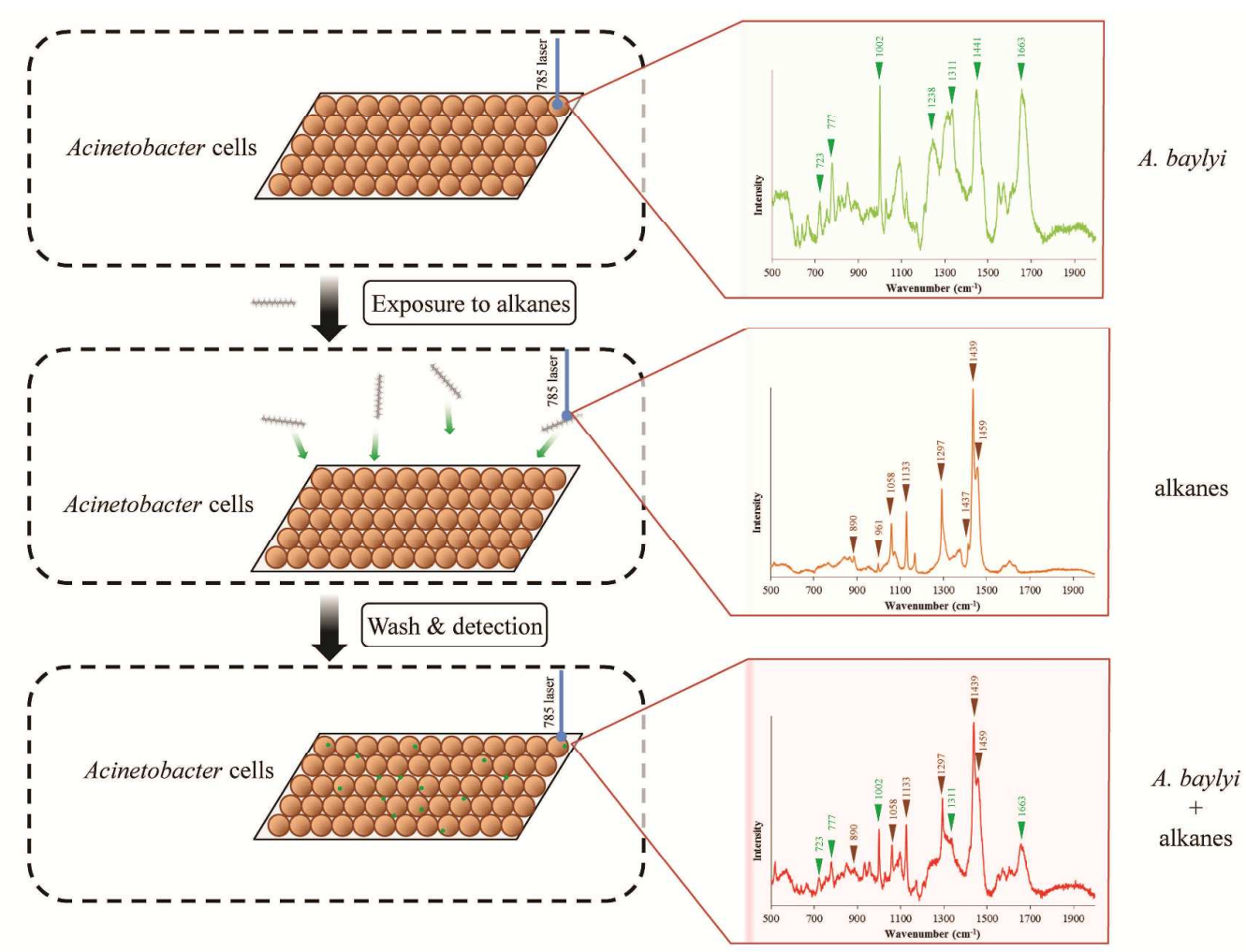

For TOC only. 